\begin{tabular}{|c|c|c|c|}
\hline \multirow{3}{*}{$\begin{array}{r}\text { Case Reports in } \\
\text { Gastroenterology }\end{array}$} & \multirow{2}{*}{\multicolumn{2}{|c|}{ Case Rep Gastroenterol 2016;10:472-478 }} & \multirow[b]{3}{*}{$\begin{array}{l}\text { Karger } \\
\text { Open access }\end{array}$} \\
\hline & & & \\
\hline & $\begin{array}{l}\text { DOI: 10.1159/000448878 } \\
\text { Publisnea onme: August 31, } 2016\end{array}$ & $\begin{array}{l}\text { (c) } 2016 \text { The Author(s) } \\
\text { Published by S. Karger AG, Basel } \\
\text { www.karger.com/crg }\end{array}$ & \\
\hline & $\begin{array}{l}\text { This article is licensed under the } \\
\text { International License (CC BY-NC) } \\
\text { Usage and distribution for commer }\end{array}$ & $\begin{array}{l}\text { nons Attribution-NonCommercial } 4.0 \\
\text { ger.com/Services/OpenAccessLicense). } \\
\text { uires written permission. }\end{array}$ & \\
\hline
\end{tabular}

\title{
Case of Six-Year Disease-Free Survival with Undifferentiated Carcinoma of the Pancreas
}

\author{
Hiroyuki Saito ${ }^{a, b}$ Hiroshi Kashiyama $^{\text {b }}$ Takashi Murohashi $^{b}$ \\ Kazunari Sasaki ${ }^{a}$ Ryosuke Misawa ${ }^{a}$ Susumu Ohwada ${ }^{a}$ \\ ${ }^{a}$ Department of Surgery, IMS Ota Central General Hospital, Ota, Japan; ${ }^{b}$ Department of \\ Surgery, Konosu Kyosei Hospital, Konosu, Japan
}

\section{Keywords}

Pancreatic carcinoma · Drug therapy · Undifferentiated carcinoma

\begin{abstract}
Undifferentiated carcinoma of the pancreas (UDC) is rare and has a dismal prognosis. Here, we report a case of 6-year disease-free survival with a mixed type of UDC and UDC with osteoclast-like giant cells, with a high mitotic index as well as perineural, lymphatic, vessel, and diaphragmatic invasion. The patient underwent radical distal pancreatectomy and was subsequently treated with adjuvant chemotherapy using gemcitabine plus S-1 followed by maintenance chemotherapy with oral tegafur-uracil. The patient has been doing well with no evidence of recurrence for more than 6 years after surgery.

\section{Background}

According to the WHO classification, undifferentiated carcinoma of the pancreas (UDC) is defined as containing large eosinophilic pleomorphic cells and/or ovoid-to-spindle-shaped cells that grow in cohesive formation, and it has a poor prognosis [1]. Undifferentiated carcinoma with osteoclast-like giant cells of the pancreas (UCOG), on the other hand, comprises pleomorphic-to-spindle-shaped cells and osteoclast-like giant cells (OGCs) and carries a bet- 
Saito et al.: Case of Six-Year Disease-Free Survival with Undifferentiated Carcinoma of the Pancreas

ter prognosis. Still, the mean survival with UCOG was reported to be only 12 months [1]. The existence of OGCs has been suggested to be one of the better prognostic factors.

Surgery is the most important treatment for UDCs so far [2]. Although the role of adjuvant chemotherapy in survival has not been ascertained yet, some reports showed promising results [3-8]. Here, we report a case of 6-year disease-free survival with a mixed UDC and UCOG with a high mitotic index and aggressive features such as perineural, lymphatic, vessel, and diaphragmatic invasion.

\section{Case Report}

A 61-year-old woman has been treated for diabetes mellitus with worsening glycemic control. In September 2009, she presented to us with upper abdominal pain. A physical examination showed upper abdominal tenderness, otherwise the examination was normal. She had a previous surgical history of cholecystectomy at the age of 37 years. A laboratory examination revealed mild anemia with a hemoglobin level of $9.8 \mathrm{~g} / \mathrm{dl}$ and a slightly impaired glucose tolerance with $159 \mathrm{mg} / \mathrm{dl}$ fasting blood glucose and $7.1 \% \mathrm{HbA}_{1 \mathrm{c}}$. Both carcinoembryonic antigen and carbohydrate antigen 19-9 levels were within normal limits. A CT scan with contrast revealed a huge, heterogeneously enhanced tumor with cystic and solid components, $10.4 \times 7.6 \times 11.5 \mathrm{~cm}$ in size, located in the tail of the pancreas (fig. 1). Endoscopic retrograde cholangiopancreatography showed irregular stricture and complete obstruction of the main pancreatic duct at the tail.

Laparotomy was done with a preoperative diagnosis of mucinous cystadenocarcinoma or acinar cell carcinoma with T3N0M0, stage IIa. As planned, distal pancreatectomy with splenectomy was performed. During the procedure, the tumor contents, consisting of old blood and necrotic tissue, were spilled over the field. The tumor also involved the left diaphragm, so that it was partially resected. The defect of the diaphragm was closed first.

\section{Postoperative Course}

The postoperative course was uneventful. Pathology confirmed UCOG with high-grade malignancy, and there was concern about microdissemination due to tumor cell spilling during the procedure. Therefore, intensive adjuvant chemotherapy with gemcitabine $(1,000$ $\mathrm{mg} /$ body; days 1 and 8) plus S-1 (80 mg/body; days 1-14, discontinued days 15-21) was given for 20 months (total of 50 courses). The initial regimen was discontinued due to a grade 3 adverse event: thrombophlebitis and arthralgia of the lower extremities. Five months later, maintenance chemotherapy was initiated with oral tegafur-uracil $\left(400 \mathrm{mg} / \mathrm{m}^{2}\right.$ body surface area daily), which was given for 15 months. Since the completion of these adjuvant chemotherapies, and after initial radical distal pancreatectomy, the patient has been doing well with no evidence of recurrence for more than 6 years.

\section{Pathological Findings}

The specimen showed a large tumor with a liquid compartment containing old blood and necrotic tissue. Microscopically, the tumor had a heterogeneous component with dense tumor cell aggregates and diffusely scattered hemorrhage beneath the fibrous capsule. Sarcomatous mononuclear cells (MNCs) with large and pleomorphic nuclei were prominent (fig. 2a). There were both atypical pleomorphic multinucleated giant cells (PGCs) and OGCs with mild nuclear pleomorphism (fig. 2a). In another part of the specimen, the MNCs were less atypical and the OGCs were bland, benign-looking, and ovoid-shaped normochromatic nuclei 
(fig. 2b). In this view, the forms of the OGCs shifted from normochromatic to mildly hyperchromatic and pleomorphic. OGCs with the latter form resembled one PGC (fig. 2b), which is suggestive of a possible transition from PGCs to OGCs. The ratio of PGCs to OGCs + PGCs was about $25 \%$. About 5 mitotic figures were observed per 10 high-power fields. The direct tumor invasion to the diaphragm as well as perineural, lymphatic, and blood vessel invasion were evident in the pathological findings. Based on these pathological findings, the tumor was diagnosed as a mixed type of UCOG and UDC of UICC T3N0M0 stage IIa.

\section{Discussion}

'Undifferentiated carcinoma of the pancreas' used to be called 'giant cell carcinoma', 'pleomorphic large cell carcinoma', or 'sarcomatous carcinoma'. In 2000, the IARC of the WHO classified them into two types: (1) UDC and (2) UCOG [1]. UDC contains large eosinophilic pleomorphic cells and/or ovoid-to-spindle-shaped cells that grow in cohesive formation. UDC is a highly malignant tumor, accompanied by high mitotic activity as well as perineural, lymphatic, and blood vessel invasion. On the other hand, UCOG is composed of both pleomorphic-to-spindle-shaped cells and OGCs and carries a better prognosis. In the WHO classification, however, there is no category treating mixed tumors which have both PGCs and OGCs, not to say the minute differentiation of mixed UDC or UCOG based on the ratio of PGCs and OGCs. Loya et al. [9] and Ezenekwe et al. [10] suggested that PGCs and OGCs might represent two ends of a single biological spectrum if both PGCs and OGCs exist in a single neoplasm. They called it 'mixed' or 'combined osteoclastic/pleomorphic giant cell tumor' $[9,10]$. In our case, both PGCs and OGCs were seen throughout the entire specimen, and the area also displayed an intermittent spectrum between PGCs and OGCs. The tumor showed aggressive features such as a high mitotic activity as well as perineural, lymphatic, and blood vessel invasion. The present case closely matched the mixed or combined osteoclastic/pleomorphic giant cell tumor described by Loya et al. [9] or Ezenekwe et al. [10]. Thus, our case might be classified as mixed UDC and UCOG (with OGCs predominating over PGCs). The WHO also reported on the difference in immunohistochemical staining between UDCs and UCOGs [1]. In UDCs, cytokeratins, vimentin, and p53 are expressed in most tumor cells, while in UCOGs they are mostly negative. OGCs are generally negative for cytokeratins and p53, but positive for vimentin, leukocyte common antigen, and macrophage markers such as KP1 [1]. K-ras oncogene mutations [11], p53 mutation [11], or E-cadherin expression [12] were reported to be prognostic predictors of both UDC and UCOG, as well as of adenocarcinoma of the pancreas. Immunohistochemical and genetic analysis may help in the differentiation between UDC, UCOG, and mixed UDC and UCOG in the near future.

There seems to be little consensus about the administration of adjuvant and neoadjuvant chemotherapy for UDC or UCOG. Thus, conventional pathological findings about the mixture of PGCs, high mitotic activity, perineural, lymphatic, and blood vessel invasion, etc., as well as genetic analysis of K-ras, p53, or E-cadherin expression will determine the necessity of adjuvant chemotherapy for UDC or UCOG. In the NCCN guidelines, FOLFIRINOX (the combination of oxaliplatin, irinotecan, fluorouracil, and leucovorin [13]) and gemcitabine plus albumin-bound paclitaxel [14] are preferred as category 1 treatment for metastatic adenocarcinoma of the pancreas [15]. These agents might be applied to UDC. Strobel et al. [2], in a relatively large number of cases (19 UDCs), reported that adjuvant or palliative chemotherapy was not associated with a greater survival benefit. On the other hand, Wakatsuki et al. [8] demonstrated a case of complete response of UDC to paclitaxel. Paclitaxel 
Saito et al.: Case of Six-Year Disease-Free Survival with Undifferentiated Carcinoma of the Pancreas

was selected according to a chemosensitivity test. The human equilibrative nucleotide transporter-1 (hENT1) appears to be an excellent predictive biomarker of response to gemcitabine in the adjuvant setting $[16,17]$. Chemosensitivity testing and hENT-1 expression might be promising candidates in determining chemotherapy regimens for UDC.

In table 1 , the reported cases are summarized regarding the chemotherapy used. Though various agents were administered, gemcitabine was used most frequently $[3-9,18$, 19]. FOLFIRINOX was utilized in 2 cases of UDC [6, 9]. A targeted therapy agent, Tarceva, was administered in 1 case [5]. The mean survival with UCOG treated with chemotherapy was more than 21 months, which was much longer than the mean survival with UCOG (12 months) [1]. These studies suggest some favorable effects of chemotherapy. The present case was treated with gemcitabine plus S- 1 for 20 months (total of 50 courses), followed by oral tegafur-uracil for 15 months, and achieved a 6-year disease-free survival, which is the longest among all reports mentioned here.

\section{Conclusions}

An accumulation of more UDC and UCOG cases would clarify the effectiveness of surgical and adjuvant/neoadjuvant treatment in the future. However, at present, complete surgical resection is the standard treatment, and adjuvant/neoadjuvant chemotherapy should be added if the clinical/pathological findings suggest high-grade malignancy.

\section{Statement of Ethics}

The authors state that the present study was approved by the hospital committee on human research and informed consent was obtained from the patient.

\section{Disclosure Statement}

The authors declare that they have no competing interests.

\section{References}

1 Klöppel G, Hruban RH, Longnecker DS, Adler G, Kern SE, Partanen TJ: Ductal adenocarcinoma of the pancreas; in Hamilton SR, Aaltonen LA (eds): WHO Classification of Tumors. Pathology and Genetics of Tumors of the Digestive System. Lyon, IARC Press, 2000, pp 221-230.

2 Strobel O, Hartwig W, Bergmann F, Hintz U, Hackert T, Grenacher L, et al: Anaplastic pancreatic cancer: presentation, surgical management, and outcome. Surgery 2011;149:200-208.

Goldberg RD, Michelassi F, Montag AG: Osteoclast-like giant cell tumor of the pancreas:

immunophenotypic similarity to giant cell tumor of bone. Hum Pathol 1991;22:618-622.

Joo YE, Heo T, Park CH, Lee WS, Kim HS, Kim JC, et al: A case of osteoclast-like giant cell tumor of the pancreas with ductal adenocarcinoma: histopathological, immunohistochemical, ultrastructural and molecular biological studies. J Korean Med Sci 2005;20:516-520.

5 Moore JC, Bentz JS, Hilden K, Adler DG: Osteoclastic and pleomorphic giant cell tumors of the pancreas: a review of clinical, endoscopic, and pathologic features. World J Gastrointest Endosc 2010;2:15-19.

-6 Jones TS, Jones EL, McManus M, Shah R, Gajdos C: Multifocal anaplastic carcinoma requiring neoadjuvant chemotherapy and total pancreatectomy: report of a case. JOP 2013;14:289-291.

7 Bauditz J, Rudolph B, Wermke W: Osteoclast-like giant cell tumors of the pancreas and liver. World J Gastroenterol 2006;12:7878-7883. 
Saito et al: Case of Six-Year Disease-Free Survival with Undifferentiated Carcinoma of the Pancreas

-8 Wakatsuki T, Irisawa A, Imamura H, Terashima M, Shibukawa G, Takagi T, Takahashi Y, et al: Complete response of anaplastic pancreatic carcinoma to paclitaxel treatment selected by chemosensitivity testing. Int J Clin Oncol 2010;15:310-313.

9 Loya AC, Ratnakar KS, Shastry RA: Combined osteoclastic giant cell and pleomorphic giant cell tumor of the pancreas: a rarity. An immunohistochemical analysis and review of the literature. JOP 2004;5:220224.

10 Ezenekwe AM, Collins BT, Ponder TB: Mixed osteoclastic/pleomorphic giant cell tumor of the pancreas: a case report. Acta Cytol 2005;49:549-553.

11 Paal E, Thompson LD, Fommelt RA, Przygodzki RM, Heffess CS: A clinicopathologic and immunohistochemical study of 35 anaplastic carcinomas of the pancreas with a review of the literature. Ann Diagn Pathol 2001;5:129-140.

-12 Yonemasu H, Takashima M, Nishiyama KI, Ueki T, Yao T, Tanaka M, et al: Phenotypical characteristics of undifferentiated carcinoma of the pancreas: a comparison with pancreatic ductal adenocarcinoma and relevance of E-cadherin, $\alpha$-catenin and $\beta$-catenin expression. Oncol Rep 2001;8:745-752.

13 Conroy T, Desseigne F, Ychou M, Bouché O, Guimbaud R, Bécouarn Y, et al: FOLFIRINOX versus gemcitabine for metastatic pancreatic cancer. N Engl J Med 2011;364:1817-1825.

14 Von Hoff DD, Ervin T, Arena FP, Chiorean EG, Infante J, Moore M, et al: Increased survival in pancreatic cancer with nab-paclitaxel plus gemcitabine. N Engl J Med 2013;369:1691-1703.

15 Tempero MA, Malafa MP, Al-Haraway M, Asbun H, Behrman SW, Benson AB, et al: NCCN clinical practice guidelines in oncology. Pancreatic adenocarcinoma. Ver 1.2016. 2016.

http://www.nccn.org/professionals/physician_gls/pdf/pancreatic.pdf (accessed April 27, 2016).

16 Nordh S, Ansari D, Andersson R: hENT1 expression is predictive of gemcitabine outcome in pancreatic cancer: a systematic review. World J Gastroenterol 2014;20:8482-8490.

$\checkmark 17$ Spratlin JL, Mackey JR: Human equilibrative nucleoside transporter 1 (hENT1) in pancreatic adenocarcinoma: towards individualized treatment decisions. Cancers (Basel) 2010;2:2044-2054.

-18 Manci EA, Gardner LL, Pollock WJ, Dowling EA: Osteoclastic giant cell tumor of the pancreas. Aspiration cytology, light microscopy, and ultrastructure with review of the literature. Diagn Cytopathol 1985;1:105-110.

19 Shinagare AB, Ramaiya NH, Bellizzi AM, Mayer RJ: Locally advanced anaplastic pancreatic adenocarcinoma with initial response to FOLFIRINOX and rapid progression after five months. Pancreatology 2012;12:35-38.

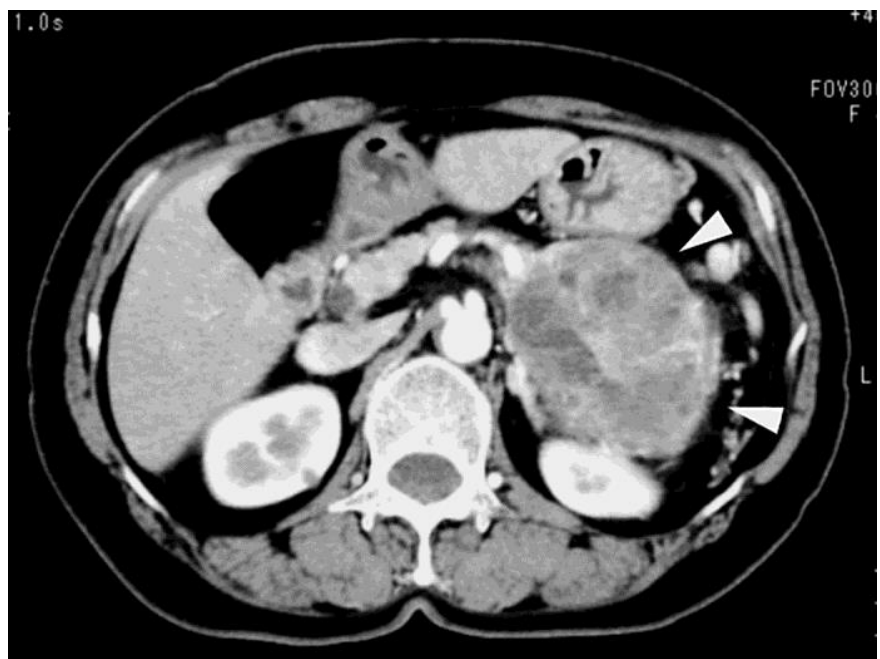

Fig. 1. A contrast-enhanced CT scan revealed a large heterogeneous tumor in the tail of the pancreas with an irregular border (arrowheads). No swollen lymph nodes were seen. 

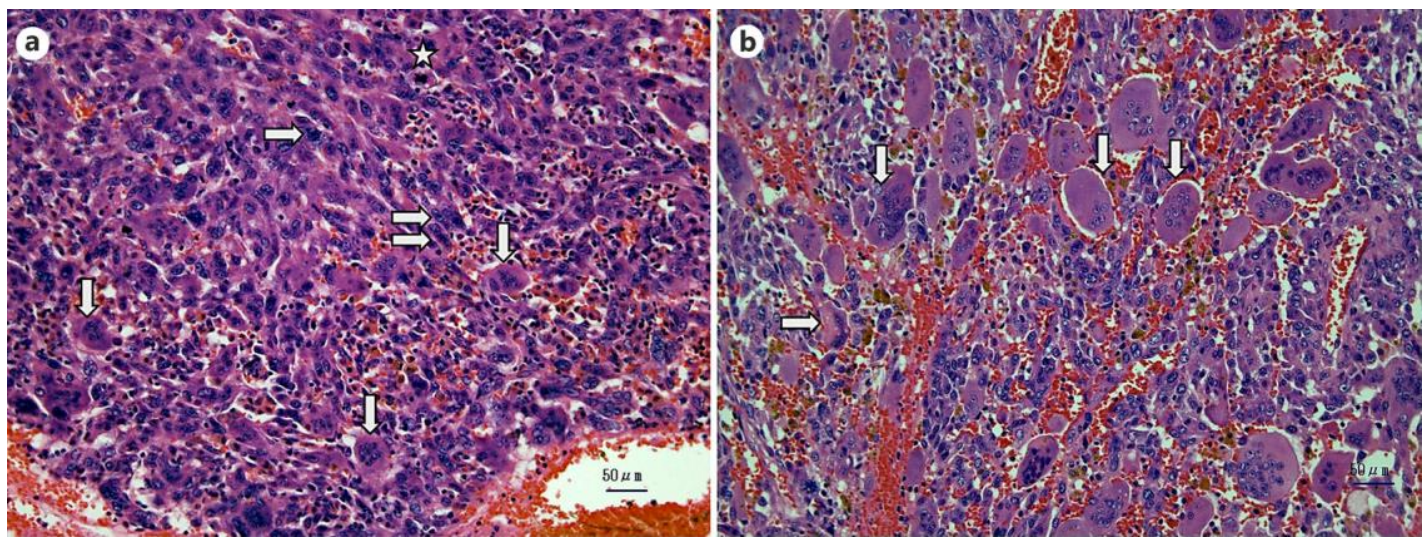

Fig. 2. Microscopic view of the specimen. a In this area, three types of cells were identified. The first were atypical PGCs, the nuclei of which were pleomorphic and hyperchromatic and contained irregular, prominent nucleoli $(\Rightarrow)$. The second were the sarcomatous MNCs with large, pleomorphic and bizarre nulei. The third were the OGCs with hyperchromatic and slightly pleomorphic nuclei ( $)$. Number of PGCs and OGCs were almost the same in this field. Mitotic figure was also observed ( $₹$ ). Original magnification $\times 200$. b In this view, MNCs were still sarcomatous but were less atypical, and there were many bland, ovoid-shaped, benign-looking OGCs with normochromatic nuclei $(\sqrt{ })$. Some OGCs had hyperchromatic, mildly pleomorphic nuclei. A pleomorphic giant cell with pleomorphic and hyperchromatic nuclei with prominent nucleoli was observed $(\Leftrightarrow)$. Original magnification $\times 200$. 
Saito et al: Case of Six-Year Disease-Free Survival with Undifferentiated Carcinoma of the Pancreas

Table 1. UDC treated with chemotherapy

\begin{tabular}{|c|c|c|c|c|c|}
\hline $\begin{array}{l}\text { Study } \\
\text { [Ref.], } \\
\text { year }\end{array}$ & Tumor type & Surgery & $\begin{array}{l}\text { Chemotherapy regimen } \\
\text { (with irradiation) }\end{array}$ & $\begin{array}{l}\text { Effect of } \\
\text { chemotherapy }\end{array}$ & Prognosis \\
\hline \multicolumn{6}{|c|}{ Resected cases } \\
\hline $\begin{array}{l}\text { Goldberg } \\
\text { et al. [3], } \\
1990\end{array}$ & UCOG & PD & $\begin{array}{l}\text { Intra- and postoperative } \\
\text { irradiation } \\
\text { Adjuvant: } 5 \text {-FU }\end{array}$ & & $\begin{array}{l}\text { Alive more than } 1 \\
\text { year from surgery }\end{array}$ \\
\hline $\begin{array}{l}\text { Loya et al. } \\
{[9], 2004}\end{array}$ & $\begin{array}{l}\text { Mixed, with } \\
\text { adeno- } \\
\text { carcinoma }\end{array}$ & PD & Adjuvant: gemcitabine & & Alive \\
\hline $\begin{array}{l}\text { Joo et al. } \\
{[4], 2005}\end{array}$ & $\begin{array}{l}\text { UCOG, with } \\
\text { ductal adeno- } \\
\text { carcinoma }\end{array}$ & DP & Adjuvant: gemcitabine & & $\begin{array}{l}\text { Alive } 6 \text { months } \\
\text { from surgery }\end{array}$ \\
\hline \multirow{2}{*}{$\begin{array}{l}\text { Moore } \\
\text { et al. [5], } \\
2010\end{array}$} & Mixed & PD & $\begin{array}{l}\text { Adjuvant: gemcitabine + } \\
\text { Tarceva }\end{array}$ & & $\begin{array}{l}\text { Alive } 13 \text { months } \\
\text { with disease }\end{array}$ \\
\hline & $\overline{\mathrm{UCOG}}$ & $\begin{array}{l}\text { PD } \\
\text { Segment } 2 \\
\text { hepatectomy } \\
\text { RFA to } 5 \text { liver } \\
\text { lesions }\end{array}$ & $\begin{array}{l}\text { Local radiation } \\
\text { Gemcitabine }\end{array}$ & & $\begin{array}{l}\text { Alive } 18 \text { months } \\
\text { from diagnosis }\end{array}$ \\
\hline $\begin{array}{l}\text { Jones et al. } \\
{[6], 2013}\end{array}$ & UDC & $\begin{array}{l}\text { TP, with vascular } \\
\text { reconstruction }\end{array}$ & $\begin{array}{l}\text { Neoadjuvant: FOLFIRINOX } \\
\text { Adjuvant: gemcitabine }\end{array}$ & $\begin{array}{l}\text { FOLFIRINOX: } \\
\text { PR }\end{array}$ & $\begin{array}{l}\text { Alive } 12 \text { months } \\
\text { from diagnosis }\end{array}$ \\
\hline $\begin{array}{l}\text { Present } \\
\text { study }\end{array}$ & UCOG & $\mathrm{DP}$ & $\begin{array}{l}\text { Adjuvant: } \\
\text { 1st line: gemcitabine + S-1 } \\
\text { 2nd line: tegafur-uracil }\end{array}$ & & $\begin{array}{l}\text { Alive more than } 6 \\
\text { years from surgery }\end{array}$ \\
\hline $\begin{array}{l}\text { Study } \\
\text { [Ref.], } \\
\text { year }\end{array}$ & $\begin{array}{l}\text { Tumor type } \\
\text { (biopsy/ } \\
\text { cytology) }\end{array}$ & $\begin{array}{l}\text { Reason for } \\
\text { inoperability }\end{array}$ & $\begin{array}{l}\text { Chemotherapy regimen } \\
\text { (with irradiation) }\end{array}$ & $\begin{array}{l}\text { Effect of } \\
\text { chemotherapy }\end{array}$ & Prognosis \\
\hline \multicolumn{6}{|c|}{ Nonresected cases } \\
\hline $\begin{array}{l}\text { Manci et } \\
\text { al. [18], } \\
1985\end{array}$ & $\begin{array}{l}\text { UCOG } \\
\text { (biopsy) }\end{array}$ & $\begin{array}{l}\text { Liver and lung } \\
\text { metastases (probe } \\
\text { laparotomy with } \\
\text { biopsy was } \\
\text { performed) }\end{array}$ & $\begin{array}{l}\text { 1st line: } 5-\mathrm{FU}+ \\
\text { doxorubicin + MMC } \\
\text { 2nd line: CDDP + } \\
\text { bleomycin + MTX }\end{array}$ & $\begin{array}{l}\text { Improved } \\
\text { symptomatology } \\
\text { after the 2nd-line } \\
\text { treatment }\end{array}$ & $\begin{array}{l}\text { Dead } 13 \text { months } \\
\text { from diagnosis }\end{array}$ \\
\hline $\begin{array}{l}\text { Bauditz } \\
\text { et al. [7], } \\
2006\end{array}$ & $\begin{array}{l}\text { UCOG } \\
\text { (biopsy) }\end{array}$ & Liver metastases & $\begin{array}{l}\text { Cisplatin, etoposide, } \\
\text { ifosfamide } \\
3 \text { cycles }\end{array}$ & $\begin{array}{l}\text { PR (significant size } \\
\text { reduction) }\end{array}$ & $\begin{array}{l}\text { Alive, with disease } \\
13 \text { months from } \\
\text { diagnosis }\end{array}$ \\
\hline $\begin{array}{l}\text { Wakatsuki } \\
\text { et al. [8], } \\
2010\end{array}$ & $\begin{array}{l}\text { UDC } \\
\text { (EUS-FNA) }\end{array}$ & $\begin{array}{l}\text { Multiple swollen } \\
\text { lymph nodes }\end{array}$ & Paclitaxel (alone) & CR & $\begin{array}{l}\text { Alive } 1 \text { year and } 11 \\
\text { months from initial } \\
\text { chemotherapy }\end{array}$ \\
\hline $\begin{array}{l}\text { Shinagare } \\
\text { et al. [19], } \\
2012\end{array}$ & $\begin{array}{l}\text { UDC } \\
\text { (EUS-FNA) }\end{array}$ & Locally invasive & FOLFIRINOX & $\begin{array}{l}\text { Marked initial } \\
\text { response (PR) } \\
\text { Disease progression } \\
6 \text { months thereafter }\end{array}$ & $\begin{array}{l}\text { Dead } 7 \text { months } \\
\text { from the first visit }\end{array}$ \\
\hline
\end{tabular}

EUS-FNA = Endoscopic ultrasound-guided fine-needle aspiration; PD = pancreaticoduodenectomy; DP = distal pancreatectomy with splenectomy; RFA = radiofrequency ablation; $\mathrm{TP}=$ total pancreatectomy; $5-\mathrm{FU}=5$-fluorouracil; $\mathrm{MMC}=$ mitomycin C; CDDP = cis-diamminedichloridoplatinum(II); MTX = methotrexate; PR = partial response; $\mathrm{CR}=$ complete response. 